\title{
A lightweight mainstream capnometer with very low dead space volume is useful monitor for neonates with spontanous and mechanical ventilation: Pilot study ${ }^{*}$
}

\author{
Daijiro Takahashi $^{1,2}$, Miyu Matsui ${ }^{1}$, Takehiko Hiroma ${ }^{1}$, Tomohiko Nakamura ${ }^{1}$ \\ ${ }^{1}$ Division of Neonatology, Nagano Children's Hospital, Nagano, Japan \\ ${ }^{2}$ Department of Pediatrics, Fukuda Hospital, Kumamoto, Japan \\ Email: tnakamura@naganoch.gr.jp
}

Received 6 February 2012; revised 8 May 2012; accepted 20 May 2012

\begin{abstract}
Objects: The purpose of this study was to observe a correlation between $\mathrm{P}_{\mathrm{ET}} \mathrm{CO}_{2}$ and $\mathrm{PaCO}_{2}$ in intubated neonates under intermittent mandatory ventilation with spontaneous breathing. Material and methods: A total of 55 paired $\mathrm{P}_{\mathrm{ET}} \mathrm{CO}_{2}$ measured by mainstream capnometry and $\mathrm{PaCO}_{2}$ values were obtained from 4 intubated neonates in our neonatal intensive care units at Nagano Children's Hospital, Nagano, Japan. Results: $\mathbf{P}_{\mathrm{ET}} \mathrm{CO}_{2}$ and $\mathrm{PaCO}_{2}$ were significantly correlated $\left(r^{2}=0.928, p<0.0001\right)$. For samples in ventilated neonates with spontaneous breathing, maximum $\mathrm{P}_{\mathrm{ET}} \mathrm{CO}_{2}$ and mean $\mathrm{P}_{\mathrm{ET}} \mathrm{CO}_{2}$ correlated strongly with $\mathrm{PaCO}_{2}$ (maximum $\mathrm{P}_{\mathrm{ET}} \mathrm{CO}_{2}: \mathrm{r}^{2}=0.9401$, $\mathrm{p}<0.0001$; mean $\left.\mathrm{P}_{\mathrm{ET}} \mathrm{CO}_{2}: \mathrm{r}^{2}=0.8587, \mathrm{p}<0.0001\right)$. Although $\mathrm{PaCO}_{2}$ also correlated with minimum $\mathrm{P}_{\mathrm{ET}} \mathrm{CO}_{2}\left(\mathrm{r}^{2}=\right.$ $0.2884, p<0.01$ ) in ventilated infants with spontaneous breathing, a significant difference was seen with maximum $\mathrm{P}_{\mathrm{ET}} \mathrm{CO}_{2}(\mathrm{p}<0.05)$ and mean $\mathrm{P}_{\mathrm{ET}} \mathrm{CO}_{2}(\mathrm{p}<$ 0.05) in the correlation coefficient $r$ between $\mathrm{PaCO}_{2}$ and $\mathrm{P}_{\mathrm{ET}} \mathrm{CO}_{2}$. Conclusion: Present study showed that a good correlation exists between $\mathrm{P}_{\mathrm{ET}} \mathrm{CO}_{2}$ and $\mathrm{PaCO}_{2}$ in intubated neonates under intermittent mandatory ventilation with spontaneous breathing. Lightweight with low amounts of dead space mainstream capnometry can be used as noninvasive monitor in incubated neonates with spontaneous breathing.
\end{abstract}

Keywords: Capnography; Neonate

\section{INTRODUCTION}

Capnography, which displays the level and waveform of $\mathrm{CO}_{2}$ in exhaled air, is a simple technique that appears to accurately indicate arterial $\mathrm{PCO}_{2}\left(\mathrm{PaCO}_{2}\right)$ and provides information on cell metabolism, blood perfusion, and

${ }^{*}$ Competing interests: The authors have no competing interests to declare. alveolar ventilation [1-3]. The use of end-tidal $\mathrm{CO}_{2}$ $\left(\mathrm{P}_{\mathrm{ET}} \mathrm{CO}_{2}\right)$ for monitoring and as a tool for verifying endotracheal tube (ETT) position is another common practice in the operating room and in adult and pediatric intensive care units [3]. This procedure was also introduced to neonatal intensive care units (NICUs), but there are limitations of the technique in smaller babies, especially for extremely low birth weight infants due to issues such as the weight of sensors or water droplets within circuits, dead space, and leakage from tracheal intubation tubes. Recently, a lightweight mainstream capnometer was developed. We have previously reported a strong correlation between $\mathrm{P}_{\mathrm{ET}} \mathrm{CO}_{2}$ and $\mathrm{PaCO}_{2}$ under controlled ventilation when tidal volume/body weight (TV/BW) was $6-15 \mathrm{~mL} / \mathrm{kg}$ and the leakage rate was $<60 \%$ in rabbits. Furthermore, under conditions of 6 $\mathrm{mL} / \mathrm{kg}$ of tidal volume (TV), $\mathrm{PaCO}_{2}$ was significantly increased by a dead space increase of only $1 \mathrm{~mL}$, representing $>7 \%$ of TV [4].

Capnometry is expected as one of the non-invasive monitor in NICUs. Although several investigators have demonstrated good relationships between values for $\mathrm{P}_{\mathrm{ET}} \mathrm{CO}_{2}$ and $\mathrm{PaCO}_{2}$ in infants [5-8], the value of capnometry in estimating $\mathrm{PaCO}_{2}$ has been questioned during anesthesia with spontaneous ventilation $[9,10]$. On the other hand, while TV is larger than spontaneous breaths, $\mathrm{P}_{\mathrm{ET}} \mathrm{CO}_{2}$ is close to the $\mathrm{PaCO}_{2}$ and to that observed with voluntary maximal expiration [11]. The purpose of this study was to observe a correlation between $\mathrm{P}_{\mathrm{ET}} \mathrm{CO}_{2}$ and $\mathrm{PaCO}_{2}$ in intubated neonates under intermittent mandatory ventilation (IMV) with spontaneous breathing.

\section{MATERIAL AND METHODS}

A total of 55 paired $\mathrm{P}_{\mathrm{ET}} \mathrm{CO}_{2}$ and $\mathrm{PaCO}_{2}$ values were obtained from the 4 neonates who had been admitted to the NICU at Nagano Children's Hospital between April and July 2009. Neonates deemed as non-viable by the attending physician were excluded, as were those with 
conditions such as acute shock, infection, or hemodynamic instability. Before enrollment into this study, informed consent was obtained from the parents or guardian of each infant. Study subjects comprised 4 neonates. Mean ( \pm standard deviation (SD)) gestational age and birth weight were $36.7 \pm 2.1$ weeks and $2446 \pm 487 \mathrm{~g}$, respectively. Data on demographics, clinical characteristics, and laboratory findings for subjects were collected by referring to the clinical laboratory records.

The infants were ventilated mechanically using a timecycled pressure-limited ventilator Calliope $^{\mathbb{B}}$; Metran, Saitama, Japan). Peak inspiratory pressure (PIP), fraction of inhaled oxygen $\left(\mathrm{FiO}_{2}\right)$, inspiratory time, positive end expiratory pressure (PEEP) and respiratory rate were settled to provide the optimal arterial $\mathrm{PaO}_{2}$ and $\mathrm{PaCO}_{2}$ as defined by the neonatologists and were not manipulated for the purposes of the study.

Mainstream $\mathrm{P}_{\mathrm{ET}} \mathrm{CO}_{2}$ was measured via a capnograph connected to the proximal end of the endotracheal tube (Cap-One ${ }^{\circledR}$; TG-970P, Nihon-Kohden, Tokyo, Japan). Data was continuously recorded on a laptop computer using the software programmed by LabVIEW (National Instruments, Texas, USA) through $\mathrm{CO}_{2}$ monitor (OLG2800; Nihon-Kohden, Tokyo, Japan) each patients. We distinguished between spontaneous breaths and ventilator breaths on the basis of capnography for $20 \mathrm{~s}$ at the time of blood gas analysis. For each 20 -s sample period, we determined the maximum, mean and minimum values of $\mathrm{P}_{\mathrm{ET}} \mathrm{CO}_{2}$ (Figure 1). Measurements of $\mathrm{P}_{\mathrm{ET}} \mathrm{CO}_{2}$ that did not show an alveolar plateau due to a large amount of leakage were excluded.

The tidal volume was measured by mainstream capnography (CO2SMO 8100, Fukuda Denshi, Tokyo, Japan). The leakage ratio was calculated using the following equation:

Leakage ratio $=\frac{(\text { Inspiratory TV }- \text { Expiratory TV })}{\text { Inspiratory TV }} \times 100$

Blood samples were drawn from indwelling arterial lines into a $0.1 \mathrm{~mL}$ heparinized syringe to prevent coagulation. Blood sampling was performed by heel puncture when arterial line was not placed. Measurements were then immediately made using a bedside blood gas analyzer (ABL 700; Radiometer, Copenhagen, Denmark) for $\mathrm{PaCO}_{2}$. Blood gas analysis was performed for the purposes of evaluation of the patient (including $\mathrm{PaO}_{2}$, $\mathrm{PaCO}_{2}$, electrolytes or lactate, etc.) only. Calibrations were performed automatically for the blood gas analyzer and the accuracy of the capnography was checked by $5 \%$ $\mathrm{CO}_{2}$ gas cylinder.

All statistical analyses were conducted using SPSS Statistics version 17.0 (SPSS, Chicago, Illinois). To determine whether $\mathrm{P}_{\mathrm{ET}} \mathrm{CO}_{2}$ were representative of $\mathrm{PaCO}_{2}$, the relationship between $\mathrm{P}_{\mathrm{ET}} \mathrm{CO}_{2}$ and $\mathrm{PaCO}_{2}$ was analyzed by simple linear regression. The standard technique of Fisher's $\mathrm{Z}$ transformation was performed to determine whether a significant difference existed in the correlation coefficient $\mathrm{r}$ between $\mathrm{PaCO}_{2}$ and each group of $\mathrm{P}_{\mathrm{ET}} \mathrm{CO}_{2}$.

Furthermore, Bland-Altman plots were performed to assess measurements of $\mathrm{P}_{\mathrm{ET}} \mathrm{CO}_{2}$. Bland-Altman plots demonstrate "good agreement" not only when differences between methods are consistent across all measurements but also when the differences are small. In a situation in which the difference between measurements is expected to change based on a third variable, Bland-Altman plots lose importance. Precision of $\mathrm{P}_{\mathrm{ET}} \mathrm{CO}_{2}$ and the agreement between $\mathrm{P}_{\mathrm{ET}} \mathrm{CO}_{2}$ and $\mathrm{PaCO}_{2}$ were assessed by bias, SD and calculating the $95 \%$ confidence interval $(\mathrm{CI})$ for the bias (bias $=\mathrm{P}_{\mathrm{ET}} \mathrm{CO}_{2}-\mathrm{PaCO}_{2}$ ). Values of $\mathrm{p}<0.05$ were determined to be significant.

This study was carried out under the control of the Ethics Committee of Medicine and Medical Care, Nagano Children's Hospital, Nagano, Japan.

\section{RESULTS}

Mean TV/BW and leakage ratio were $7.3 \pm 1.7 \mathrm{~mL} / \mathrm{kg}$ and $9.5 \% \pm 12.0 \%$, respectively (Table 1). All patients were treated using sedative drugs.

$\mathrm{P}_{\mathrm{ET}} \mathrm{CO}_{2}$ and $\mathrm{PaCO}_{2}$ were significantly correlated $\left(\mathrm{r}^{2}=\right.$ $0.928, \mathrm{p}<0.0001)$. In the Bland-Altman plot test, the mean difference (bias) and SD of the differences for

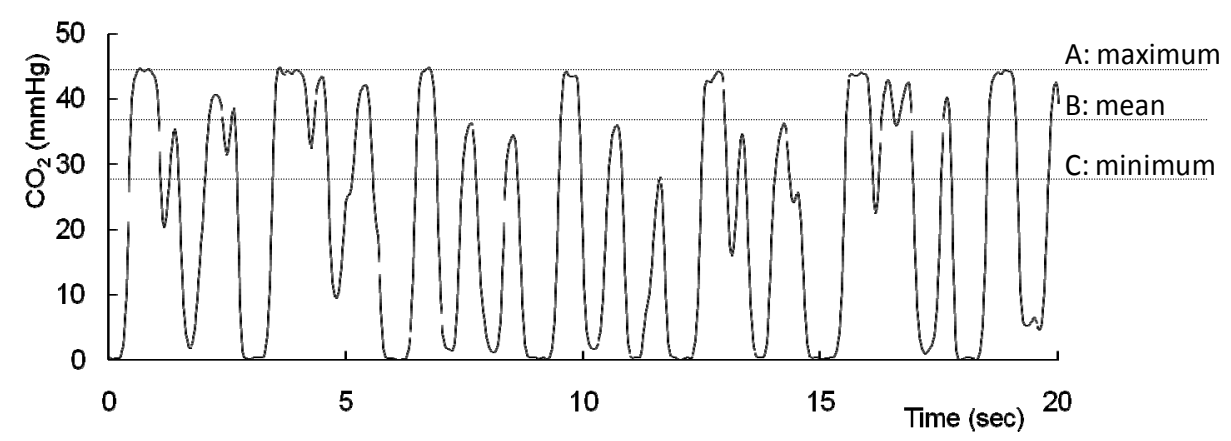

Figure 1. Continuous recording of $\mathrm{P}_{\mathrm{ET}} \mathrm{CO}_{2}$. For each $20 \mathrm{~s}$ sample period, we determined maximum $\mathrm{A}$, mean $\mathrm{B}$ and minimum $\mathrm{CP}_{\mathrm{ET}} \mathrm{CO}_{2}$. 
Table 1. Baseline characteristics.

\begin{tabular}{lc}
\hline \multicolumn{1}{c}{ Characteristics } & Number of patients \\
\hline Sex & 3 \\
Male & 1 \\
Female & \\
Inborn/Outborn & 3 \\
Inborn & 1 \\
Outborn & 2 \\
Underlying disease & 1 \\
Congenital heart disease & 1 \\
Intraventricular hemorrhage & \\
Perioperative management & $36.7 \pm 2.1$ \\
Gestational age (week) & $34-39$ \\
Mean \pm SD & \\
Range & $2446 \pm 487$ \\
Birthweight (g) & $1778-2894$ \\
Mean \pm SD & \\
Range & \\
Tidal volume/Body weight (mL/kg) & \\
Mean \pm SD & \\
Range & \\
Leakage ratio (\%) & \\
Mean \pm SD & \\
Range & \\
\hline & \\
& \\
&
\end{tabular}

$\mathrm{P}_{\mathrm{ET}} \mathrm{CO}_{2}$ was $-0.88 \pm 2.69 \mathrm{mmHg}(95 \% \mathrm{CI}$ for the bias, -1.61 to $-0.16 \mathrm{mmHg}$ ) (Figure 2). We chose the maximum for $\mathrm{P}_{\mathrm{ET}} \mathrm{CO}_{2}$ on the basis of capnograms for each 20 $\mathrm{s}$ period at the time of blood gas analysis.

Due to breath-to-breath variation, we evaluated three measurements of $\mathrm{P}_{\mathrm{ET}} \mathrm{CO}_{2}$ to determine which one most consistently and accurately predicted $\mathrm{PaCO}_{2}$. From 55

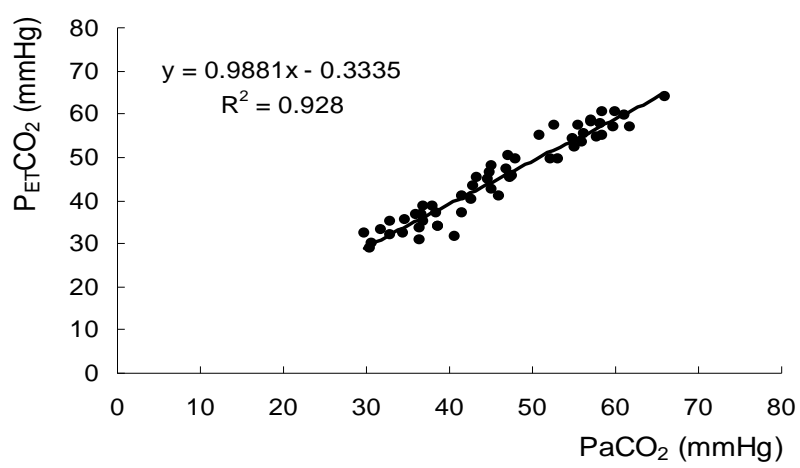

(a) measurements, we have selected 24 paired $\mathrm{P}_{\mathrm{ET}} \mathrm{CO}_{2}$ and $\mathrm{PaCO}_{2}$ values which were obtained at the time when spontaneous breathing was present.

For samples in ventilated infants with spontaneous breathing, maximum $\mathrm{P}_{\mathrm{ET}} \mathrm{CO}_{2}$ and mean $\mathrm{P}_{\mathrm{ET}} \mathrm{CO}_{2}$ correlated strongly with $\mathrm{PaCO}_{2}$ (maximum $\mathrm{P}_{\mathrm{ET}} \mathrm{CO}_{2}: \mathrm{r}^{2}=$ $0.9401, \mathrm{p}<0.0001$; mean $\mathrm{P}_{\mathrm{ET}} \mathrm{CO}_{2}: \mathrm{r}^{2}=0.8587, \mathrm{p}<$ 0.0001). Although $\mathrm{PaCO}_{2}$ also correlated with minimum $\mathrm{P}_{\mathrm{ET}} \mathrm{CO}_{2}\left(\mathrm{r}^{2}=0.2884, \mathrm{p}<0.01\right)$ in ventilated infants with spontaneous breathing, a significant difference was seen with maximum $\mathrm{P}_{\mathrm{ET}} \mathrm{CO}_{2}(\mathrm{p}<0.05)$ and mean $\mathrm{P}_{\mathrm{ET}} \mathrm{CO}_{2}(\mathrm{p}<$ $0.05)$ in the correlation coefficient $r$ between $\mathrm{PaCO}_{2}$ and $\mathrm{P}_{\mathrm{ET}} \mathrm{CO}_{2}$ (Figures 3(a)-(c)).

Bland-Altman analysis showed that $\mathrm{P}_{\mathrm{ET}} \mathrm{CO}_{2}$ underestimated $\mathrm{PaCO}_{2}$ by a mean difference (bias) of $-0.175 \pm$ $2.31 \mathrm{mmHg}$ (95\% CI for the bias, -1.15 to $0.799 \mathrm{mmHg}$ ) in the maximum $\mathrm{P}_{\mathrm{ET}} \mathrm{CO}_{2},-5.01 \pm 3.55 \mathrm{mmHg}(95 \% \mathrm{CI}$ for the bias, -6.50 to $-3.51 \mathrm{mmHg}$ ) in mean $\mathrm{P}_{\mathrm{ET}} \mathrm{CO}_{2}$, and $-14.6 \pm 8.82 \mathrm{mmHg}(95 \% \mathrm{CI}$ for the bias, -18.3 to -10.9 $\mathrm{mmHg}$ ) in minimum $\mathrm{P}_{\mathrm{ET}} \mathrm{CO}_{2}$ (Figures 3(d)-(f)).

\section{DISCUSSION}

Advances in the treatment of neonatal respiratory failure, including exogenous surfactant $[12,13]$, inhaled nitric oxide (iNO) [14,15], and a growing repertoire of assisted ventilation strategies [16] have decreased morbidity and mortality rates. Patient monitoring has played a critical role in the safe and effective application of these advanced therapies.

Pulse oximetry provides a noninvasive method of assessing oxygenation and continuous surveillance of the partial pressure of arterial oxygen [17]. Maintaining $\mathrm{PaCO}_{2}$ within the desired range by frequent arterial sampling can increase the need for multiple transfusions in the NICU [18], highlighting the need for methods of continuous non-invasive monitoring of $\mathrm{CO}_{2}$ levels. Both hypocarbia and hypercarbia are detrimental to extremely low birth weight infants and have been implicated as

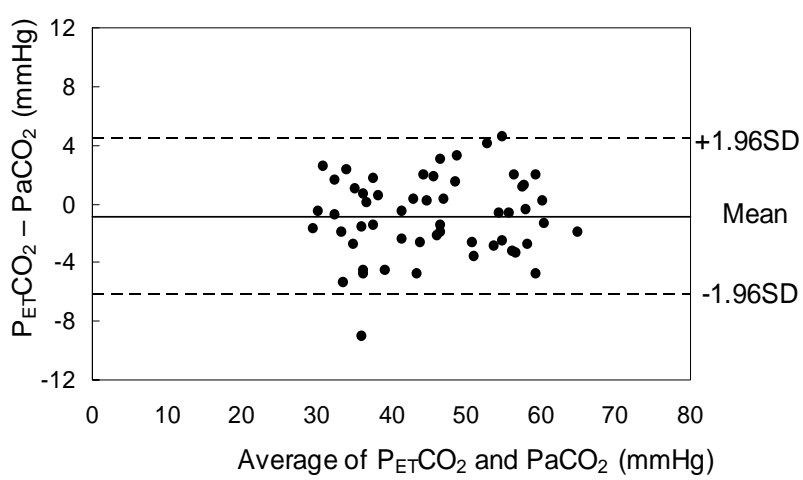

(b)

Figure 2. The relationship between $\mathrm{P}_{\mathrm{ET}} \mathrm{CO}_{2}$ and $\mathrm{PaCO}_{2}$ (a) and Bland-Altman plot shows bias against average values of $\mathrm{P}_{\mathrm{ET}} \mathrm{CO}_{2}$ and $\mathrm{PaCO}_{2}$ in ventilated infants (b). $\mathrm{P}_{\mathrm{ET}} \mathrm{CO}_{2}$ and $\mathrm{PaCO}_{2}$ were significantly correlated $\left(\mathrm{r}^{2}=0.928, \mathrm{p}<0.0001\right)$. 


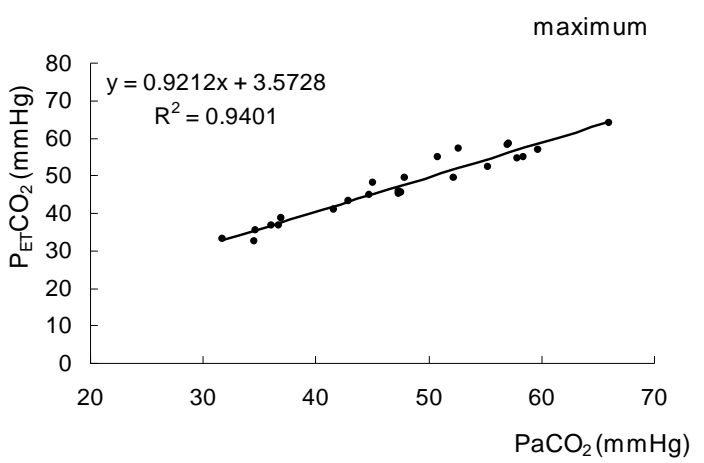

(a)

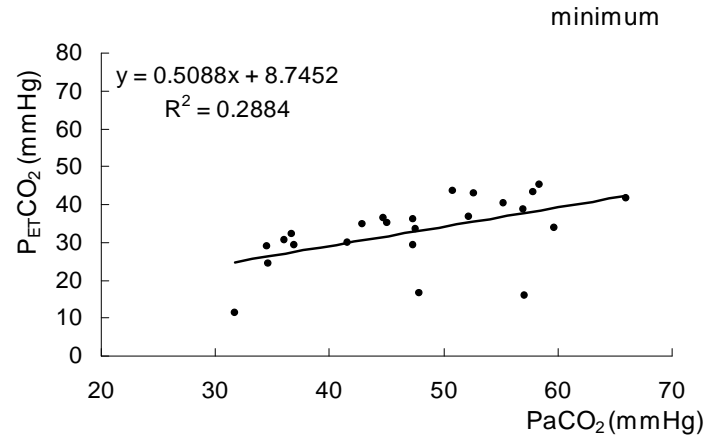

(c)

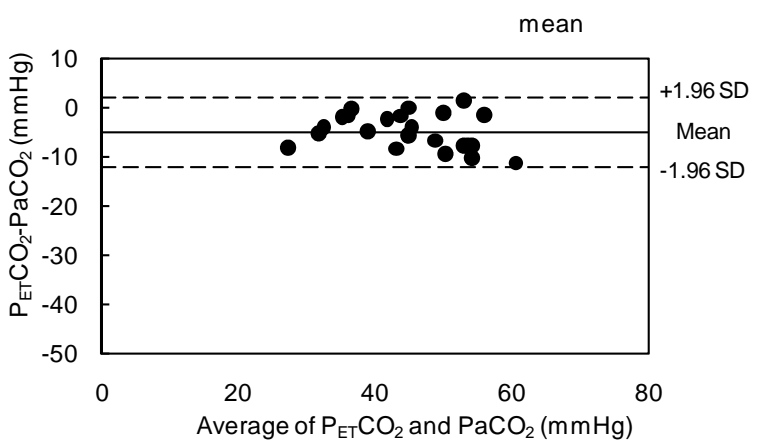

(e)

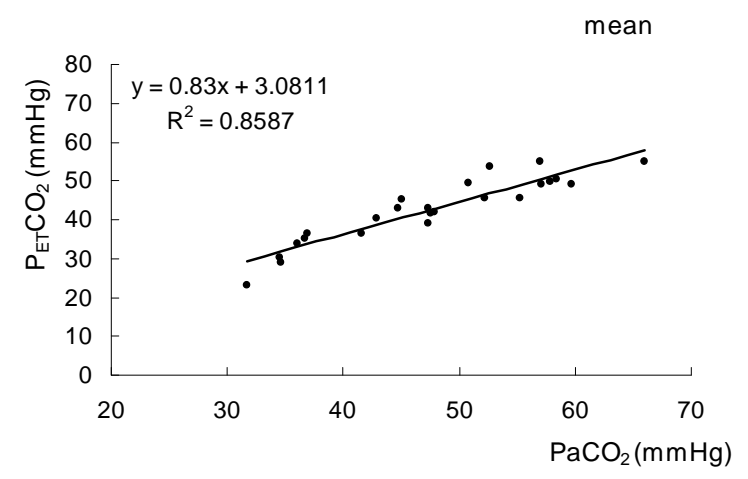

(b)

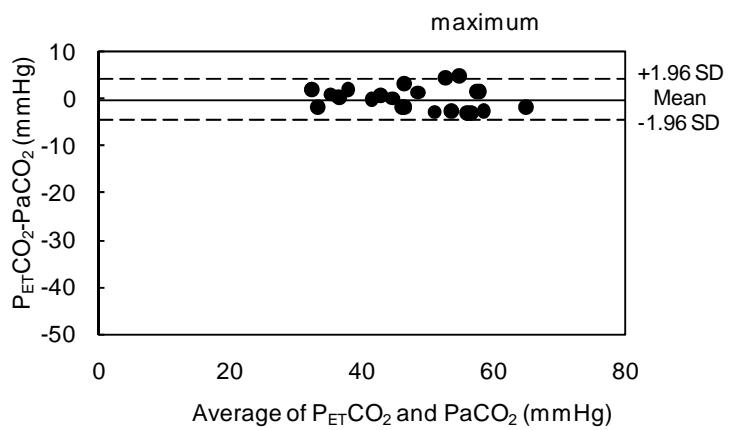

(d)

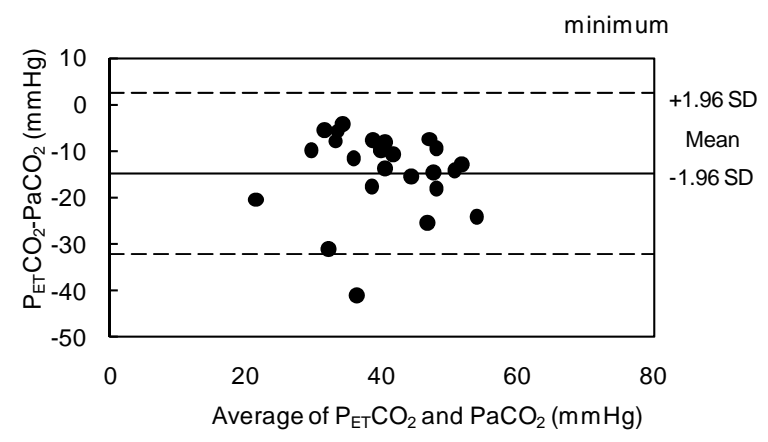

(f)

Figure 3. The relationship between $\mathrm{P}_{\mathrm{ET}} \mathrm{CO}_{2}$ and $\mathrm{PaCO}_{2}$ (a), (b) and (c) and Bland-Altman plot shows bias against average values of $\mathrm{P}_{\mathrm{ET}} \mathrm{CO}_{2}$ and $\mathrm{PaCO}_{2}$ in ventilated infants with spontaneous breathing (d), (e) and (f). Maximum $\mathrm{P}_{\mathrm{ET}} \mathrm{CO}_{2}$ and mean $\mathrm{P}_{\mathrm{ET}} \mathrm{CO}_{2}$ correlated strongly with $\mathrm{PaCO}_{2}$. Conversely, $\mathrm{PaCO}_{2}$ did not correlate with minimum $\mathrm{P}_{\mathrm{ET}} \mathrm{CO}_{2}$.

causative factors in periventricular leukomalacia, intraventricular hemorrhage and chronic lung disease [19-21]. Critical event analyses have documented that hypoxemia secondary to depressed respiratory activity is a principal risk factor for near misses and death [22,23].

Monitoring of $\mathrm{P}_{\mathrm{ET}} \mathrm{CO}_{2}$ is a simple and noninvasive technique that appears to accurately indicate $\mathrm{PaCO}_{2}$ in a variety of clinical situations [1,24]. However, levels of $\mathrm{P}_{\mathrm{ET}} \mathrm{CO}_{2}$ and $\mathrm{PaCO}_{2}$ depend on ventilation, cardiac output, $\mathrm{CO}_{2}$ output, and pulmonary function; a change in any of these will cause a change in $\mathrm{P}_{\mathrm{ET}} \mathrm{CO}_{2}$ [25]. For instance, a growing degree of difference between $\mathrm{P}_{\mathrm{ET}} \mathrm{CO}_{2}$ and $\mathrm{PaCO}_{2}$ can indicate the severity of pulmonary embolism [26] or even the effects of thrombolytic therapy [27].
$\mathrm{P}_{\mathrm{ET}} \mathrm{CO}_{2}$ varied appreciably from breath to breath. The reliability of this value under conditions of significant ventilation perfusion inequality or heterogeneous tidal volumes has thus been questioned [28]. In many cases, spontaneous breaths of variable tidal volumes far outnumbered ventilator breaths, but still contributed relatively little to alveolar minute ventilation. We found that maximum $\mathrm{P}_{\mathrm{ET}} \mathrm{CO}_{2}$ during each sampling period showed the best correlation with $\mathrm{PaCO}_{2}$. A number of investigators have suggested that larger tidal volumes are necessary to measure $\mathrm{P}_{\mathrm{ET}} \mathrm{CO}_{2}$ accurately, as small (e.g., spontaneous) breaths may fail to "wash out" the anatomic dead space [11,29].

Weinger et al. [30] also found a wide range in differ- 
ences between $\mathrm{P}_{\mathrm{ET}} \mathrm{CO}_{2}$ and $\mathrm{PaCO}_{2}$ over time. However, they measured mean peak $\mathrm{P}_{\mathrm{ET}} \mathrm{CO}_{2}$ over a period of $8 \mathrm{~min}$. Although averaging maximal $\mathrm{P}_{\mathrm{ET}} \mathrm{CO}_{2}$ values over a longer time span might improve the stability and reliability of $\mathrm{PaCO}_{2}-\mathrm{P}_{\mathrm{ET}} \mathrm{CO}_{2}$, assessing the respiratory status to measure $\mathrm{P}_{\mathrm{ET}} \mathrm{CO}_{2}$ over a long time would be difficult. The respiratory apparatus might change second to second.

Takano et al. [31] reported that reliable $\mathrm{P}_{\mathrm{ET}} \mathrm{CO}_{2}$ was obtained when a vital capacity maneuver was performed on each nonintubeted patient, indicating that full expiration to the maximal expiratory position is necessary for precise estimation of $\mathrm{PaCO}_{2}$.

Comparison with spontaneous breathing, end tidal $\mathrm{CO}_{2}$ measured from ventilated breath is close to the $\mathrm{PaCO}_{2}$ and to that observed with a voluntary maximal expiration. This $\mathrm{PCO}_{2}$ gradient between ventilator and spontaneous breathing indicates a large dead-space to tidal volume ratio; much of the expired $\mathrm{CO}_{2}$ appearing with spontaneous breathing is diluted, with dead space air lowering the concentration at any point during expiration.

Although our prospective observational study revealed a good correlation and agreement between $\mathrm{PaCO}_{2}$ and maximum $\mathrm{P}_{\mathrm{ET}} \mathrm{CO}_{2}$, the present study included only a very small number of participants, and the conditions of patients were not constant. Furthermore, in children with congenital cyanotic heart disease, right-to-left intracardiac shunting reportedly causes an obligatory difference between $\mathrm{PaCO}_{2}$ and $\mathrm{P}_{\mathrm{ET}} \mathrm{CO}_{2}$ [32,33]. Our subjects included patients with congenital heart disease because they showed stable cardiorespiratory status in this study.

This study consisted of only a small number of participants, the statistical implications of repeated measurements in the same infants, and the conditions of the cases were not constant. In addition, we did not adjust for cardiac output their measurements, though differences in cardiac output are known to affect $\mathrm{P}_{\mathrm{ET}} \mathrm{CO}_{2}$ measurements [25]. Therefore, we would like to study these issues in the future.

\section{CONCLUSION}

Our results indicate that a good correlation exists between $\mathrm{P}_{\mathrm{ET}} \mathrm{CO}_{2}$ and $\mathrm{PaCO}_{2}$ in intubated neonates under intermittent mandatory ventilation with spontaneous breathing. Furthermore, maximum $\mathrm{P}_{\mathrm{ET}} \mathrm{CO}_{2}$ correlated strongly with $\mathrm{PaCO}_{2}$ compared to minimum $\mathrm{P}_{\mathrm{ET}} \mathrm{CO}_{2}$. Lightweight with low amounts of dead space mainstream capnometry can be used as noninvasive monitor in incubated neonates with spontaneous breathing.

\section{ACKNOWLEDGEMENTS}

The authors acknowledge the help and support of Mr. Dainobu, Mr.
Inoue, and Mr. Yamamori from Nihon Kohden.

\section{REFERENCES}

[1] Burton, G.W. (1966) The value of carbon dioxide monitoring during anaesthesia. Anaesthesia, 21, 173-183. doi:10.1111/j.1365-2044.1966.tb02596.x

[2] Burton, G.W. (1969) Measurement of inspired and expired oxygen and carbon dioxide. British Journal of Anaesthesia, 41, 723-730. doi:10.1093/bja/41.9.723

[3] Bhende, M.S. (2001) End-tidal carbon dioxide monitoring in pediatrics - Clinical applications. Journal of Postgraduate Medicine, 47, 215-218.

[4] Takahashi, D., Hiroma, T. and Nakamura, T. (2011) $\mathrm{P}_{\mathrm{ET}} \mathrm{CO}_{2}$ measured by a new lightweight mainstream capnometer with very low dead space volume offers accurate and reliable noninvasive estimation of $\mathrm{PaCO}_{2}$. Research and Reports in Neonatology, 1, 61-66.

[5] Meyer, R.E. and Short, C.E. (1985) Arterial to end-tidal $\mathrm{CO}_{2}$ tension and alveolar dead space in halothane- or isoflurane-anesthetized ponies. American Journal of Veterinary Research, 46, 597-599.

[6] Geiser, D.R. and Rohrbach, B.W. (1992) Use of end-tidal $\mathrm{CO}_{2}$ tension to predict arterial $\mathrm{CO}_{2}$ values in isoflurane-anesthetized equine neonates. American Journal of Veterinary Research, 53, 1617-1621.

[7] Riker, J.B. and Haberman, B. (1976) Expired gas monitoring by mass spectrometry in a respiratory intensive care unit. Critical Care Medicine, 4, 223-229. doi:10.1097/00003246-197609000-00002

[8] McEvedy, B.A., McLeod, M.E., Kirpalani, H., Volgyesi, G.A. and Lerman, J. (1990) End-tidal carbon dioxide measurements in critically ill neonates: A comparison of side-stream and mainstream capnometers. Canadian Journal of Anesthesia, 37, 322-326. doi:10.1007/BF03005583

[9] Hagerty, J.J., Kleinman, M.E., Zurakowski, D., Lyons, A.C. and Krauss, B. (2002) Accuracy of a new low-flow sidestream capnography technology in newborns: A pilot study. Journal of Perinatology, 22, 219-225. doi:10.1038/sj.jp.7210672

[10] Bhat, Y.R. and Abhishek, N. (2008) Mainstream endtidal carbon dioxide monitoring in ventilated neonates. Singapore Medical Journal, 49, 199-203.

[11] Kugelman, A., Zeiger-Aginsky, D., Bader, D., Shoris, I. and Riskin, A. (2008) A novel method of distal end-tidal $\mathrm{CO}_{2}$ capnography in intubated infants: Comparison with arterial $\mathrm{CO}_{2}$ and with proximal mainstream end-tidal $\mathrm{CO}_{2}$. Pediatrics, 122, e1219-e1224. doi:10.1542/peds.2008-1300

[12] Lee, K., Khoshnood, B., Wall, S.N., Chang, Y., Hsieh, H.L. and Singh, J.K. (1999) Trend in mortality from respiratory distress syndrome in the United States, 19701995. Journal of Pediatrics, 134, 434-440. doi:10.1016/S0022-3476(99)70200-3

[13] Rodriguez, R.J. and Martin, R.J. (1999) Exogenous surfactant therapy in newborns. Respiratory Care Clinics of 
North America, 5, 595-616.

[14] Wessel, D.L., Adatia, I., Van Marter, L.J., Thompson, J.E., Kane, J.W., Stark, A.R., et al. (1997) Improved oxygenation in a randomized trial of inhaled nitric oxide for persistent pulmonary hypertension of the newborn. Pediatrics, 100, E7. doi:10.1542/peds.100.5.e7

[15] Cornfield, D.N., Maynard, R.C., de Regnier, R.A., Guiang, S.F., Barbato, J.E. and Milla, C.E. (1999) Randomized, controlled trial of low-dose inhaled nitric oxide in the treatment of term and near-term infants with respiratory failure and pulmonary hypertension. Pediatrics, 104, 1089-1094. doi:10.1542/peds.104.5.1089

[16] Plavka, R., Kopecky, P., Sebron, V., Svihovec, P., Zlatohlavkova, B. and Janus, V. (1999) A prospective randomized comparison of conventional mechanical ventilation and very early high frequency oscillatory ventilation in extremely premature newborns with respiratory distress syndrome. Intensive Care Medicine, 25, 68-75. doi:10.1007/s001340050789

[17] Dziedzic, K. and Vidyasagar, D. (1989) Pulse oximetry in neonatal intensive care. Clinics in Perinatology, 16, 177197.

[18] Madsen, L.P., Rasmussen, M.K., Bjerregaard, L.L., Nohr, S.B. and Ebbesen, F. (2000) Impact of blood sampling in very preterm infants. Scandinavian Journal of Clinical and Laboratory Investigation, 60, 125-132. doi:10.1080/00365510050184949

[19] Giannakopoulou, C., Korakaki, E., Manoura, A., Bikouvarakis, S., Papageorgiou, M., Gourgiotis, D., et al. (2004) Significance of hypocarbia in the development of periventricular leukomalacia in preterm infants. Pediatrics International, 46, 268-273. doi:10.1111/j.1442-200x.2004.01886.x

[20] Erickson, S.J., Grauaug, A., Gurrin, L. and Swaminathan, M. (2002) Hypocarbia in the ventilated preterm infant and its effect on intraventricular haemorrhage and bronchopulmonary dysplasia. Journal of Paediatrics and Child Health, 38, 560-562. doi:10.1046/j.1440-1754.2002.00041.x

[21] Wallin, L.A., Rosenfeld, C.R., Laptook, A.R., Maravilla, A.M., Strand, C., Campbell, N., et al. (1990) Neonatal intracranial hemorrhage: II. Risk factor analysis in an inborn population. Early Human Development. 23, 129137. doi:10.1016/0378-3782(90)90136-7

[22] Strauss, R.G. (1991) Transfusion therapy in neonates. American Journal of Disease of Children, 145, 904-911.

[23] Wiswell, T.E., Graziani, L.J., Kornhauser, M.S., Stanley, C., Merton, D.A., McKee, L., et al. (1996) Effects of hy- pocarbia on the development of cystic periventricular leukomalacia in premature infants treated with high-frequency jet ventilation. Pediatrics, 98, 918-924.

[24] Gothard, J.W., Busst, C.M., Branthwaite, M.A., Davies, N.J. and Denison, D.M. (1980) Applications of respiratory mass spectrometry to intensive care. Anaesthesia, 35, 890-895. doi:10.1111/j.1365-2044.1980.tb03950.x

[25] Ornato, J.P., Garnett, A.R. and Glauser, F.L. (1990) Relationship between cardiac output and the end-tidal carbon dioxide tension. Annals of Emergency Medicine, 19, 1104-1106. doi:10.1016/S0196-0644(05)81512-4

[26] Hatle, L. and Rokseth, R. (1974) The arterial to end-expiratory carbon dioxide tension gradient in acute pulmonary embolism and other cardiopulmonary diseases. Chest, 66, 352-357. doi:10.1378/chest.66.4.352

[27] Verschuren, F., Heinonen, E., Clause, D., Roeseler, J., Thys, F., Meert, P., et al. (2004) Volumetric capnography as a bedside monitoring of thrombolysis in major pulmonary embolism. Intensive Care Medicine, 30, 2129-2132. doi:10.1007/s00134-004-2444-9

[28] Capan, L.M., Ramanathan, S., Sinha, K. and Turndorf, H. (1985) Arterial to end-tidal $\mathrm{CO}_{2}$ gradients during spontaneous breathing, intermittent positive-pressure ventilation and jet ventilation. Critical Care Medicine, 13, 810-813. doi:10.1097/00003246-198510000-00007

[29] Evans, J.M., Hogg, M.I. and Rosen, M. (1977) Correlation of alveolar $\mathrm{PCO}_{2}$ estimated by infra-red analysis and arterial $\mathrm{PCO}_{2}$ in the human neonate and the rabbit. British Journal of Anaesthesia, 49, 761-764. doi:10.1093/bja/49.8.761

[30] Weinger, M.B. and Brimm, J.E. (1987) End-tidal carbon dioxide as a measure of arterial carbon dioxide during intermittent mandatory ventilation. Journal of Clinical Monitoring, 3, 73-79. doi:10.1007/BF00858353

[31] Takano, Y., Sakamoto, O., Kiyofuji, C. and Ito, K. (2003) A comparison of the end-tidal $\mathrm{CO}_{2}$ measured by portable capnometer and the arterial $\mathrm{PCO}_{2}$ in spontaneously breathing patients. Respiratory Medicine, 97, 476-481. doi:10.1053/rmed.2002.1468

[32] Fletcher, R. (1991) The relationship between the arterial to end-tidal $\mathrm{PCO}_{2}$ difference and hemoglobin saturation in patients with congenital heart disease. Anesthesiology, 75, 210-221. doi:10.1097/00000542-199108000-00007

[33] Short, J.A., Paris, S.T., Booker, P.D. and Fletcher, R. (2001) Arterial to end-tidal carbon dioxide tension difference in children with congenital heart disease. British Journal of Anaesthesia, 86, 349-353. doi:10.1093/bja/86.3.349 